This is an Accepted Manuscript of an article published by West European Politics, available online: https://doi.org/10.1080/01402382.2017.1403148

\title{
Democratic regeneration in European peripheral regions: new politics for the territory?*
}

\author{
Matthias Scantamburlo $^{\mathrm{a}}$, Sonia Alonso ${ }^{\mathrm{b}}$, and Braulio Gómez ${ }^{\mathrm{a}}$ \\ ( ${ }^{a}$ University of Deusto) \\ $\left({ }^{\mathrm{b}}\right.$ Georgetown University in Qatar)
}

\begin{abstract}
Scholarly research on the emergence of a new politics agenda of democratic regeneration, driven by the electoral growth of challenger parties, has focused the analysis primarily at the national and supranational levels, leaving the subnational level underexplored. This article contributes to filling this gap through a comparative analysis of party competition in peripheral regions of Italy, Spain and Great Britain during the European Great Recession. Using Regional Manifestos Project data, it shows that the regionalisation of the state and the presence of a centre-periphery cleavage represent no obstacle when it comes to responding to a change of preferences among the electorate. The transformation of political spaces in the aftermath of the Great Recession is happening as much at the regional as at the national level. At the same time, the political relevance of challenger parties and the diversity of regional responses contradict the alleged secondary nature of regional dynamics.
\end{abstract}

Keywords: regionalist parties; regional elections; new politics; party competition; democratic regeneration; centre-periphery conflict

\footnotetext{
* We thank the special issue editors Thomas Däubler, Jochen Müller, and Christian Stecker as well as the anonymous reviewers for their very thoughtful comments.
} 
This article analyses the effect that the changing preferences of European electorates during the Great Recession has had on party offer in regions characterised by a historically salient centreperiphery conflict. Scholarly research on the emergence of a 'new politics' (Hutter et al. 2017) agenda has focused the analysis primarily at the national and supranational (i.e. European) levels, leaving the subnational level under-explored. In this article, we want to fill this gap while contributing to the larger discussion about the virtues and/or vices of regionalisation for democratic representation in Europe (Däubler et al. 2017).

The political crisis in the shadow of the Great Recession contributed to processes of change in many Western European party systems. While the modification of electoral alignments in some countries favoured the extant populist radical left and right, in others it led to the rise of new parties campaigning against the political establishment and for a regeneration of democracy. Their transformative agenda has resonated with voters, who, having removed their trust in establishment parties $^{1}$, voted in considerable numbers for these new politics parties (Hobolt and Tilley 2016). According to previous research (Hobolt and Tilley 2016; Hutter et al. forthcoming; Ruiz-Rufino and Alonso 2017), voters punish establishment parties for their contribution to bring about the Great Recession, but also, and more fundamentally, voters show a deeper dissatisfaction with the functioning of democracy. As a result, the regeneration of democracy has been successfully incorporated onto the political agendas of many European countries (Hutter et al. 2017).

\footnotetext{
${ }^{1}$ Following Alonso and Ruiz-Rufino (forthcoming), we define political establishment parties as 'those historical centre-left and centre-right parties that have dominated the political agenda during the postWWII period and have, therefore, been key actors in the design of the existing national and European institutions, either as incumbent parties or as the main opposition in parliament'. Eurobarometer survey results between 2007, 2010 and 2016 show the low and decreasing trust towards political parties in the three countries under analysis: While in Spain 32\% of respondents trusted political parties in 2007, the number fell to $11 \%$ in 2010 and further to $10 \%$ in 2016 . Although smaller in absolute terms, the fall of trust in Italy, from 16\% in 2007 and 2010 to $9 \%$ in 2016, is also dramatic, particularly given the already low level of trust to begin with. Trust in parties was also very low in United Kingdom before the onset of the crisis in 2007, 15\%, and has remained almost unchanged for the following ten years (13\% in 2010, $14 \%$ in 2016). (Source: Eurobarometer n. 68, 74, 86).
} 
It is our contention here that this challenge to the political establishment does not only take place at the national level but also at the subnational one (regional and local ${ }^{2}$ ). Establishment parties have been losing votes in regional and local elections across Europe while new parties campaigning for the need to regenerate democracy have established themselves as permanent features of subnational party systems (Hobolt and Tilley 2016). Who are these establishment parties at the regional level? That hinges upon the structure of political conflict that exists in each country and, within each country, in each region.

In politically decentralised countries with a salient centre-periphery conflict, such as those under analysis in this article, the regional branches of state-wide parties share the political space with the regionalist party family, whose positions along the centre-periphery dimension spread from regionalism and autonomism to separatist nationalism (Alonso 2012). In the last two to three decades these parties moved 'from protest to power' (Elias and Tronconi 2011), often reaching governing status and becoming key players, at both the regional and national levels (Schakel and MAssetti 2017). Challengers in the past, they are now being in turn challenged by the electoral growth of new parties born in the shadow of the Great Recession to defend an intense anti-establishment agenda. How have establishment parties reacted to the emergence of this new politics agenda in regions characterised by complex bi-dimensional political spaces? Has the change in voters' preferences been picked up and acted upon by regional party systems? What has been the response of regionalist parties, the old challengers, to this new challenge? These are the questions that this article aims to answer.

To do so, we compare peripheral regions across three West European countries - namely Italy, Spain and United Kingdom, where the centre-periphery cleavage is highly salient (Alonso 2012; Elias et al. 2015) and where changes in electoral alignments are transforming partisan

\footnotetext{
${ }^{2}$ New politics parties govern many important cities of Italy and Spain, including the capitals.
} 
politics (Bosco and Verney 2016; Hernández and Kriesi 2016; Kriesi 2014). We analyse the period between 2007 and 2016, which captures the evolution of the Great Recession, from its origin in the global financial meltdown at the end of 2007 to the present. Within this ten-year period, 2010 marks a turning point. This is the year when the sovereign debt crisis broke out, marked by the first bailout of a Eurozone country, Greece. The story has been told many times ${ }^{3}$. What matters for our argument are its consequences. The economic interventions of the socalled Troika in several Eurozone countries between 2010 and 2013 limited national governments autonomy to make fiscal policy decisions, being bound by the signature of Memoranda of Understanding to implement harsh internal devaluation programs (Armingeon et al. 2016; Copelovitch et al. 2016). Calls to democratic regeneration at the national and European levels for greater responsiveness and less technocracy, against the Troika and in favour of national sovereignty and the 'will of the people', seemed far more plausible after 2010.

The aim here is to conduct a pioneering exploration by following our intuition that establishment parties at the regional level react to the transformation of partisan politics by emphasizing issues of democratic regeneration and making electoral use of them in regional party competition. We thus, on the one hand, confirm further the strategic capacity of regionalist actors to strategise beyond centre-periphery issues, as already demonstrated by other studies (Alonso 2012; Massetti 2009; Zuber 2012) and, on the other hand, show the effects of the transformation of partisan politics at the sub-national level leading to the increased relevance of democratic regeneration in party competition.

The article is structured as follows. We first introduce the theoretical background regarding subnational party positioning on issues of democratic regeneration. This leads us to the

\footnotetext{
${ }^{3}$ See Copelovitch et al. (2016) for an excellent chronology and analysis.
} 
expectations that will guide our comparative analysis. The fourth section introduces our data, operationalisation, and relevant cases. In the empirical sections, five and six, we present our main findings. We conclude with a discussion of our comparative analysis and the implications of the results for future research.

\section{Economic crisis and party competition on democratic regeneration}

The relationship between economy and party system stability in old and new democracies constitutes a classic subject of analysis in political science (Thomassen 1990). Although we do not know exactly if more economic development increases stability, we do know that economic hardship encourages the instability of party systems as voters hold incumbents responsible for the course of the economy and try to find new political alternatives (Casal Bértoa 2014: 5). In contrast to times of 'normal politics', when the traditional opposition constitutes the alternative (economic voting), a major economic crisis like the European Great Recession constitutes a 'critical juncture' whereby the whole political establishment is under threat, thus accelerating pre-existing long-term processes of party system change (Hernández and Kriesi 2016: 204).

The rise of new parties during the Great Recession is strongly linked to the erosion of the established parties' representation function (Mair 2013). The limitation of the old parties' capacity to sustain their political offer based on the traditional political conflicts contributed to the generation of anti-elitist feelings among Western European electorates. In some countries the disaffection with the 'old' political class has been channelled by the new populist phenomenon of the 'anti-party', which is mobilizing around the rejection of the party system as a whole (Kriesi 2014: 370). While the most striking example is surely Grillo's Five Star Movement (M5S) in Italy, also other contexts show that the upsurge of new forces is best explained by the lack of confidence in political institutions, as Orriols and Cordero (2016) confirm for Podemos and Ciudadanos in Spain. 
Hutter et al. (2017) conceptualise the political space that followed the 2007 outbreak of the Great Recession as constituted by two 'overlapping conflicts': the conflict with the domestic national- elites and the conflict with the European -EU- elites, each one having in turn a political and an economic component. The conflict with European elites is based on the EU's management of the financial crisis and the EU's democratic deficit. The concrete issues, however, may differ across countries. In Southern Europe, it is mainly about ending the Troikaimposed austerity and its conditions; in Great Britain it is more about the lack of economic policy autonomy brought about by the Stability and Growth Pact. In all cases, on the other hand, it is about taking back national sovereignty and democratizing European decision-making.

The conflict with EU elites spills over to the national level. In the economic realm, the conflict over EU-imposed austerity translates into the domestic arena in terms of the old socioeconomic left-right dimension. The issues here concern the (fair) distribution of the economic costs of the crisis and the regulation of markets. At the same time, the loss of national sovereignty caused by EU and Euro membership triggers calls for taking it back. In Southern Europe, moreover, corruption and clientelism have aggravated the already deficient response of the political establishment to the sovereign debt crisis. The perception of corruption coupled with the limited manoeuvring space of national governments has increased the distrust towards both domestic and European political institutions (Muro and Vidal 2017) and fuelled the electoral challenge represented by new parties.

To sum up, new politics or the regeneration of democratic practices is not just about politics, but also about the economy: it comes, so to speak, with a call for economic policies that are more responsive to the needs of the people, not the elites, and that are based on deliberation by the people, not on the opinion of experts and/or unelected institutions. This is reflected in an emphasis on (anti)austerity and democratic regeneration when addressing both national and European elites (Hutter et al. 2017). 


\section{New politics and regional party competition}

Countries with a salient centre-periphery cleavage are characterised by a complex space of political competition. The traditional left-right conflict has evolved alongside, either crosscutting or overlapping, a centre-periphery dimension (Alonso 2012; Elias et al. 2015; Massetti 2009). This complexity is compounded by the multilevel structure of the state and its effects on the national and subnational party systems. In regional and local elections, the subnational branches of state-wide parties compete with territorially bounded regional and local parties for the support of voters. As a result, party systems in regions with a salient centre-periphery conflict are more fragmented than elsewhere in the country, making government formation more complex and coalition governments more common (Van Haute and Deschouwer 2017).

Regionalist parties are parties whose political agenda is the defence of a distinctive territory inside the state (Rokkan and Urwin 1983). They constitute the regionalist party family since they are all rooted in the centre-periphery cleavage, defined 'as the conflict over the political control over a (peripheral) territory' (Alonso 2012: 25). A second feature that distinguishes them from regional branches of state-wide parties is the exclusive organisation in their peripheral territory (Alonso et al. 2017). It has been widely demonstrated, in response to the niche party thesis (Meguid 2008), that many regionalist parties do not limit their appeal to centre-periphery issues but instead complement their territorial self-government goals with the position and emphasis on a different set of economic and other issues (Alonso 2012; Gross and Debus 2017; Massetti and Schakel 2015).

Regarding the political conflict around democratic regeneration, the emergence of challenger parties at the national level has had its counterpart at the regional one. Regionalist parties have emerged that combine, with no apparent difficulty, a pro-periphery agenda (that goes from enhanced self-government to outright separatism) with a new politics worldview, critical of the political and economic establishment (see section 5). 
Given the empirically demonstrated strategic nature of regionalist parties, and their status as 'establishment' parties in many regions, we expect them to react to the emergence of new challengers by accommodating their agendas to those of their competitors (Alonso 2012). On the other hand, the regional branches of state-wide parties are also expected to react strategically to the growth of new politics parties by addressing issues of democratic regeneration in electoral contests. Ignoring new politics would be too risky for establishment parties, regionalist and state-wide alike, particularly in the context of the Great Recession. Therefore, our first hypothesis runs as follows:

(H1) The electoral growth of challenger parties defending agendas of democratic regeneration in regional elections will eventually lead to the increased salience of these issues in the regional space of political competition.

As a result, the whole space of political competition will be transformed. However, this process against the secondary nature of regional dynamics will be more than a mere reflection of the changes unfolding at the national level and will depend on how parties combine new politics issues with the other salient dimensions to form regionally-specific 'issue packages' ${ }^{4}$. Despite some general trends that are likely to exist across regions, we expect different combinations of new politics and the two other main regional dimensions of competition, the left-right and the centre-periphery cleavage.

Likewise, we also expect variations across types of parties in the way new politics is combined with other issue dimensions to conform the party's image. The new challengers are expected to emphasise to a comparatively larger degree new politics issues, i.e. democratic

\footnotetext{
${ }^{4}$ We follow here Alonso et al.'s (2017) use of the notion of 'issue package'. According to it, parties use their programmatic saliencies and positions strategically along a wide range of issue dimensions. The assumption is that there is more than one way to convey a pro- or anti- position along one particular conflict dimension by combining issues belonging to different dimensions. This issue package is what conveys to the electorate a particular party 'image'.
} 
regeneration, whereas the old establishment parties are expected to respond to the challenge by engaging with the economic aspects linked to new politics (as demonstrated by Hutter et al. forthcoming), i.e. the conflict over the distribution of the costs of the crisis. The reason behind this is party credibility. Convincing the electorate that a party will reform institutional procedures to make them more democratic, to reduce corruption, and to increase the 'sovereignty of the people' will be difficult for establishment parties that have been steering the political life of a country for decades, either as incumbents or as main opposition. It would be more likely that a party having a 'clean record' exploits these issues (Bågenholm and Charron 2014: 906). The economic aspects, by contrast, can be more credibly handled by old establishment parties, since they can use strategies of blame avoidance that redirect blame for economic outcomes onto European institutions, international markets and globalisation. Therefore, our second hypothesis says that:

(H2) For reasons of partisan credibility, old establishment parties will accommodate the democratic regeneration agendas of new challenger parties indirectly, by emphasizing the economic aspects of new politics to a larger degree than the more political ones.

The implication of $\mathrm{H} 2$ is that the difference between establishment and new parties is larger than the difference between regionalist and state-wide parties. In other words, irrespective of which category establishment parties in the region belong to (state-wide or regional) they will be more similar amongst them than with respect to new parties, whether these are state-wide or regional. Thus, the regionalist party family will be divided by the new politics conflict dimension as much as it was divided in the past by the left-right conflict dimension (Alonso 2012; Alonso et al. 2015; Massetti and Schakel 2015). 


\section{Measuring new politics in parties' regional-level manifestos}

This article uses data from the content analysis of parties' electoral manifestos to measure the salience of new politics in regional elections. More concretely, we rely on the data of the Regional Manifestos Project (RMP). The content-analysis methodology used by the RMP is an adaptation of the Manifesto Research on Political Representation's (MARPOR) contentanalysis classification scheme, developed for the analysis of multilevel polities. This adaptation is described and explained in Alonso et al. (2013).

We rely on Hutter et al.'s (forthcoming) conceptualisation of the new politics conflict dimension and its relationship with economic issues, already introduced in section 2. In this section we proceed to operationalise it using RMP salience scores. Table 1 shows the policy issues that belong to the new politics and the economic austerity conflict dimensions. New politics is constituted by issues that relate to the betterment of democracy in general and to representative and/or participative democratic institutions in particular. Also included are all references critical of corruption. Finally, European integration is an important element of new politics for it addresses the supra-national institutional environment in which existing European national democracies are embedded. Both positive and negative mentions of European integration belong to the new politics dimension because new politics party challengers are not necessarily anti-EU but can also be anti-existing EU and pro-renewed EU.

[Table 1 about here]

The same logic applies to the second conflict over economic austerity. Being translated into the core conflict between the market and the state, it comprises two different views on tackling economic hardship. The market represents the arena of complete economic freedom (categories 401, 407, 414) and the state represents the intervention of government on the 
economy to guarantee a more equal distribution of wealth (categories 403, 404, 406, 409, 412). Austerity policies belong to category 414 and 407, whereas anti-austerity would be addressed by categories 409 and 406 . Hutter et al. (forthcoming) include welfare issues in this dimension but we disagree with this since welfare policy issues, at least at the regional level, are part of the old establishment parties' manifestos and their traditional issue package ${ }^{5}$. Moreover, welfare issues do not serve to differentiate between left- and right-wing parties because welfare is highly mentioned by parties across the ideological spectrum, as already demonstrated by Benoit and Däubler (2014).

The salience of new politics issues in party manifestos is calculated as the percentage of quasi-sentences in a manifesto assigned to the aforementioned categories. Theoretically, the salience of new politics ranges from 0 , for a party manifesto that completely ignores the dimension, to 100, for a party manifesto that dedicates all its sentences to it. Empirically, however, the range in our data set goes from $0.28 \%$ (Scottish Labour Party in 2011) to 22.91\% (M5S Trentino in 2013).

We are also interested in two other major political conflicts that have been present in the regions under analysis at least since WWII (Alonso 2012): the left-right and the centreperiphery dimensions. An established, though no doubt controversial, way of measuring the salience of the left-right dimension in the literature is using the right-left (RILE) variable, the operationalisation developed by the MARPOR team and whose categories are listed in the Appendix. The problem with RILE is that some of its categories are also used to define the economic austerity conflict. For this reason, we will use them alternatively in the analysis, never

\footnotetext{
${ }^{5}$ The relation between the salience of the centre-periphery cleavage and the active promotion of subnational systems of welfare governance is clear. Territorial mobilisation has favoured the process of welfare building at the sub-state level with regionalist parties using social policies to emphasise the distinctiveness of their territories (Vampa 2016). What further matters for our argument is that the imposed fiscal constraints during the Great Recession have reinforced this discourse in their challenge against the central-state. Alonso et al. (2017) show the high attention to welfare issues in old regionalist parties' post-crisis election manifestos.
} 
together. To measure the salience of the centre-periphery dimension we shall use the operationalisation developed by the RMP's team, and whose categories are also shown in the Appendix.

Our main empirical indicators throughout this article are salience scores. Salience scores have both an absolute and a relative meaning (Alonso 2012). Concerning the former, we need to know what the salience scores mean in terms of the absolute degree of attention that parties' manifestos give to the different issue dimensions. In other words, we need some yardstick defining what high- and low-salience scores are. For this purpose, following Alonso (2012), we have calculated the mean salience score of the 76 policy categories in our three countries under study. This value is 1.3 , with a standard deviation of 2.19. Any policy category whose salience score is $1.3 \%$ or more is considered to receive a salient degree of attention by parties in their electoral manifestos. Therefore, when the salience score of the new politics or economic austerity conflict dimensions is below $1.3 \%$ of mentions, we can say that the party manifesto is ignoring these issues.

Concerning the relative meaning, our interest is not the absolute salience score of each dimension but the relative weight that each dimension represents over the whole manifesto. For this, we calculate the ratio between the salience scores of the two dimensions being compared: the new politics dimension, which is our dimension of interest, and the reference dimension. Ratios larger than 1 indicate that the new politics dimension is more important in the party manifestos than the reference dimension; ratios lower than 1 indicate the opposite. The larger than 1 the ratio, the more important the new politics dimension is relative to the reference dimension; the lower than 1 the ratio, the less important the new politics dimension is relative to the reference dimension. 


\section{Case selection}

Italy, Spain and Great Britain are asymmetrically decentralised states, where some regions have a higher level of self-government than others. This asymmetry is the result of a historically successful politicisation of the centre-periphery conflict by regionalist and/or nationalist parties. Therefore, our analysis focuses on those regions with a higher level of self-government, characterised by the presence of politically relevant regionalist parties competing for votes side by side with the regional branches of state-wide parties.

Our data cover 33 parties (24 regionalist and 9 state-wide parties), 8 of which are new politics challenger parties, operating in 13 regions (4 regions in Italy, 7 in Spain and 2 in Great Britain). Table A2 in the Appendix shows the full list of regions and parties in our dataset. Regionalist and state-wide parties have been categorised according to the above definition that separates them from each other, i.e. roots in the centre-periphery conflict and territorial organisation. Pertaining to both categories, new politics challenger parties have been identified as those parties that commonly share a fierce anti-establishment rhetoric and were created and/or gained representation at the subnational level only in the aftermath of the European Great Recession (i.e. after 2007).

Our argument on the transformation of political spaces applies only to establishment parties: those that have been a long-term feature of the regional party system, with long governing -or opposition- experience. Established parties have incentives to react to new challengers as they have electoral, organisational, and institutional interests to protect. Smaller parties do not. Given the relative smaller size that characterises regionalist parties, we apply Massetti's (2009) minimum electoral relevance criterion, which consists in selecting parties that have elected representatives to the regional assembly on at least three consecutive 
occasions. Regarding state-wide establishment parties, we consider the two largest ones in their respective countries ${ }^{6}$.

\section{The new politics party challengers in Italy, Spain and Great Britain: A general overview}

New challenger parties are the driving forces behind the transformation of the political spaces in times of crisis (Hobolt and Tilley 2016; Hutter et al. forthcoming). While the challenge to the establishment is their common feature, the parties analysed in this article raise specific policy demands and differ in organisation as well as in their historical background.

Founded in 2009 the Italian M5S has been labelled as the best example of the new 'antiparty' (Kriesi 2014) stating to neither be left nor right and contraposing Italian citizens against the corrupt elites. It claims that power can be given back to the citizens through online direct democracy, which is also a new main feature of party organisation (Ceccarini and Bordignon 2016). Relying on direct democracy in the fight against the establishment is also a central point in the programme of Podemos in Spain, which grew out of the $15 \mathrm{M}$ social movement and first contested elections in 2014. Although adopting a M5S-like neither-left-nor-right strategy in order to appeal to the 'social majority', the party can be clearly placed on the left, competing against its right-wing counterpart Ciudadanos (Citizens, C's). Founded in 2006 as a Catalonian anti-nationalist party, its take-off outside Catalonia started in the 2015 regional elections (Rodríguez Teruel and Barrio 2016). Unlike M5S, Podemos and C's, the United Kingdom Independence Party (UKIP) is an 'old' challenger, existing since 1993, but entering mainstream politics only after 2009. Adopting an open Eurosceptic and anti-immigrant position, it has been characterised as part of a broader European populist radical right (Ford et al. 2012).

\footnotetext{
${ }^{6}$ Because of the dissolution of the Italian main centre-right coalition Popolo della Libertà (PdL) and the little relevance of state-wide centre-right parties in the selected regions, we only included manifestos of the Democratic Party.
} 
New politics party challengers exist also at the regional level. They all campaign for a regeneration of democracy but can also be clearly placed on the (far) left of the political spectrum. The Galician Alternative Left (AGE) and the Valdostan Autonomy Freedom Participation and Ecology (ALPE), are splinters from the historically dominant regionalist parties (Galician Nationalist Bloc -BNG- and Valdostan Union -UV- respectively) and form coalitions with regional green parties. The other Valdostan party, Progressive Valdostan Union (UVP), also split from the UV in 2013, adopting a similar stance to ALPE, with whom it formed an electoral coalition. The Catalan Popular Unity Candidacy (CUP) differs from the others in its historical background, which can be traced back to the Spanish democratic transition. Since then the party promoted its anti-capitalist, ecologist, and municipalist platform contesting elections only at the local level until 2012, when it entered the regional political scene. Despite their common emphasis on democratic regeneration and far left positions, these regionalist parties differ in their centre-periphery positioning. While the Spanish regionalist challengers combine their democratic regeneration claims with secessionist positions, the Italian regionalist challengers display autonomist stances.

The electoral fortunes of these new challengers have varied across party types. The regionalist challengers generally obtained remarkable electoral results from the beginning (see Table A3 in the Appendix). Being organised at the national level, the electoral fortunes of the state-wide challengers are more diverse across electoral levels and regions. Whereas the M5S became the largest party at its debut on the national stage in 2013 with $25.6 \%$, at the regional level it only gradually consolidated itself as a third force behind the traditional centre-left and right (from an average of $3.3 \%$ in 2010 to $16.3 \%$ in 2015). The territorial distribution of M5S vote shares ranges from $2.5 \%$ in South Tyrol to $22.3 \%$ in Liguria, thus showing a large diversity across regions (Scantamburlo and Pallaver 2014; Vampa 2015). Similarly, the UKIP in 2014 became the largest party at the European level with $27 \%$, whereas at the regional level it 
achieved representation for the first time in Wales in 2016, when it nearly trebled its share of votes compared to 2011 (from $4.7 \%$ to $12.5 \%$ ). Podemos and C's were much more successful in their first regional challenge against the Spanish two-party system, achieving $20 \%$ of the regional vote and entering all regional parliaments at the 2015 regional elections. Moreover, they proved decisive in forming regional governments in 10 out of the 17 Spanish autonomous communities, whether via investiture agreements or legislative pacts (Gómez and Urquizu 2015).

Let us turn now to challenger parties' programmatic agendas. Figure 1 presents the salience scores of the major conflict dimensions in new challenger parties' manifestos. The salience of new politics issues in challenger parties' manifestos ranges from $9.4 \%$ in UKIP to $18 \%$ in M5S. The left-right dimension, on the other hand, shows a range between $15.7 \%$ (UKIP) and $47 \%$ (AGE) whereas the centre-periphery dimension moves between $1.85 \%$ and $13 \%$. Some patterns emerge from these results. The new politics dimension shows the smallest diversity, meaning that these parties are more similar in terms of the emphasis they give to democratic regeneration than in relation to the other two dimensions of competition. At the same time, state-wide parties dedicate considerably less space in their manifestos to the centre-periphery conflict than regionalist parties, as is to be expected. The left-right dimension presents the largest diversity of the three.

[Figure 1 about here]

A look into the relative weight of the new politics dimension relative to the economic austerity dimension shows a clear picture in favour of new politics (Figure 2). In all cases except the Catalan CUP, challenger parties give more relative weight to the new politics dimension than to issues concerning economic austerity. Clearly, it is democratic regeneration that they 
are most preoccupied with, not economic justice. UKIP, Podemos, M5S and UVP emphasise the new politics dimension more than twice as much as the economic austerity one. In the other cases, the relative weight is more balanced, although always clearly in favour of the new politics dimension. The only case in which the economic austerity dimension is more salient than the new politics one is the CUP. This makes sense in terms of this party's historical background as a far-left party.

[Figure 2 about here]

\section{Responding to new politics challengers: the transformation of regional political spaces}

In the previous section, we have briefly introduced the programmatic agenda of new politics challenger parties. In this section, we are going to analyse the response of establishment parties to this new development in their respective regions. We have divided the sample into two periods marked by the year 2010 . The year 2010, as we already explained, marks a temporal tipping point after which establishment parties can no longer ignore the newly emerging conflict, as they are immersed in the European Great Recession. Thus, the first period includes the last regional elections that occurred before or in 2010; the second period represents the regional elections, which took place after the year 2010 (see Table A4 in the Appendix). For some regions, we have data for two electoral cycles. For this reason, the second period has two sub-periods: 1st post-2010 and 2nd post-2010, referring to the first and second regional elections after the year 2010 .

\section{The transformation of regional spaces of political competition (H1)}

According to our first hypothesis, we should see an increase in the salience of new politics and 
economic austerity dimensions on the part of at least some establishment parties such that the space of political competition is transformed to include those issues in the regional electoral agenda. Figure 3 and Table A5 in the Appendix show the evolution of new politics and economic austerity salience scores before and after 2010. The salience scores represent average values for all parties in the region, excluding new challenger parties.

[Figure 3 about here]

Let us begin our discussion with the new politics dimension. Out of 13 regions, 11 (85\%) saw an increase in the level of attention dedicated by establishment parties to issues of democratic regeneration, as we expected. In 7 regions (54\%), the salience increased by more than 1.3 points (our absolute salience yardstick); in the remaining 4 regions (31\%), by less than 1 point. Only 2 regions (15\%) saw a u-shaped evolution, by which there was an initial decrease in the salience of new politics issues between the last pre-2010 election and the first post-2010 one, followed by an increase in the second post-2010 electoral cycle. These regions are the Basque Country and the Canary Islands. In terms of percentage change, Scotland and Wales are the regions where the attention dedicated to democratic regeneration increased the most, more than trebling its level in Scotland and more than doubling it in Wales. Their starting levels were, however, extremely low (almost 0). The British regions are followed by Galicia, which almost doubled the attention paid to democratic regeneration in regional electoral manifestos between 2009 and 2012, Catalonia and Veneto.

Turning now to the economic austerity dimension, only in 2 out of 13 regions the attention dedicated to economic austerity issues decreased, growing in the rest of them (85\%). A majority of the regions ( 7 , or 54\%), however, saw only a moderate increase with only 4 regions $(31 \%)$ seeing a growth larger than 1.3 points. In terms of percentage change, the increase was largest 
in Galicia and Aosta. These regions are followed by the Basque Country and Catalonia. Overall, the attention dedicated to democratic regeneration since the emergence of new challenger parties shows a larger increase relative to the economic austerity dimension, but both types of issues have become more salient after 2010, as expected by our first hypothesis. This is even more the case if we compare the increase in the salience of new politics and economic austerity issues between the last regional election pre-2010 and the second electoral cycle post-2010.

Another way to measure the transformation of the regional spaces of political competition is by looking at changes in the relative weight of the new politics dimension relative to the other two major dimensions, left-right and the centre-periphery (Table 2). When the ratio increases from the pre-2010 election to the post-2010 election it is because the new politics dimension is gaining relative weight inside the party manifestos in relation to the reference dimension.

Table 2 shows the different ways in which parties combine new politics issues with the other issue dimensions to conform regionally-specific issue packages. In 8 out of 13 regions $(61.5 \%)$, the relative weight of the new politics dimension grows at the expense of both the leftright and the centre-periphery dimensions: the ratio is larger after 2010 than before. However, this ratio is almost always lower than 1 , meaning that the reference dimension (left-right or centre-periphery) still dominates the new politics dimension in the party manifestos. In terms of percentage change, the new politics dimension grows more at the expense of the centreperiphery than the left-right dimension except in three regions, the Basque Country, Catalonia and South Tyrol, the latter being the only region where parties give more weight to centreperiphery than to left-right issues in relation to democratic regeneration.

[Table 2 about here] 


\section{Establishment parties versus new challengers (Hypothesis 2)}

Our second hypothesis claims that old establishment parties are more likely to accommodate the democratic regeneration agendas of new politics challenger parties indirectly, by emphasizing the economic aspects to a larger degree than the more political ones. In this sense, we expect all establishment parties to behave similarly. This means that the differences between state-wide and regionalist parties with regards to the centre-periphery dimension of competition disappear when it comes to the new politics and economic austerity conflict dimensions. Figure 4 shows the change of new politics, economic austerity and centre-periphery salience scores before and after 2010 .

[Figure 4 about here]

Our hypothesis finds no clear confirmation in the data. Establishment parties increase the attention paid to new politics and economic austerity issues after 2010, as expected according to our first hypothesis. However, there does not seem to be more emphasis on the economic austerity dimension at the expense of the new politics one. State-wide parties overall emphasise economic austerity more than regionalist parties, but this is the only pattern showed by the data in this respect.

There are, however, other interesting results. The regionalist party family is much more heterogeneous after the emergence of these new party challengers. It is clearly divided by the new politics conflict dimension. New regionalist parties emphasise new politics and economic austerity issues much more than establishment regionalist parties. At the same time, new regionalist parties give much less relevance to the centre-periphery dimension than establishment regionalist parties, which continue to stick to their old programmatic agendas that differentiate them from state-wide parties. Moreover, new regionalist parties also give more 
salience to new politics and economic austerity issues than new state-wide parties while, they simultaneously differ from new state-wide parties in their larger emphasis of centre-periphery issues, as is to be expected from regionalist parties.

In order to delve further into these findings, Table 3 compares the relative weight of the new politics dimension relative to the economic austerity, the centre-periphery, and the leftright dimensions. The ratio between new politics and economic austerity will give us a more accurate indicator with which to test our hypothesis than the absolute salience scores. Establishment regionalist parties give more relative emphasis to new politics in relation to either the economic austerity or the left-right dimension than state-wide parties. The relative emphasis of new politics, however, decreases between the pre-2010 and the post-2010 for both party families, which seems to go in the direction of our prediction. By contrast, in relation to the centre-periphery dimension, establishment state-wide parties emphasise new politics to a much larger degree than regionalist parties, and there is no change between electoral cycles. As is to be expected, given that new challenger parties bring a new conflict dimension into the space of competition, they give much more emphasis to new politics issues than to centre-periphery ones in comparison to establishment parties. This applies to both new state-wide parties and new regionalist parties.

[Table 3 about here]

\section{Concluding remarks}

The main objective of this article was to provide a descriptive answer to the following questions: How have establishment parties reacted to the emergence of a new politics agenda in regions characterised by complex bi-dimensional political spaces? Has the change in voters' 
preferences been picked up and acted upon by regional party systems? What has been the response of regionalist parties, the old challengers, to the electoral growth of new politics party challengers? The relevance of these questions is two-fold: on the one hand, it fills a gap in the literature on the transformation of national political spaces of competition in Europe by looking at the sub-national level; on the other hand, it introduces the notion that establishment parties can be of two types, state-wide or regionalist, and that both have incentives, as establishment parties, to react to the challenge that new politics parties represent.

Firstly, we have shown that, as expected, regional political spaces of competition have been transformed by the emergence and electoral growth of challenger parties with agendas that are highly critical of the political establishment. Establishment parties have reacted by partly accommodating the agenda of democratic regeneration and economic justice, increasing the attention dedicated to these issues in their regional party manifestos. The degree of accommodation of the new politics programmatic agenda varies greatly across regions, partly because of the type of challenger party, and partly, we assume, because of the diversity of regional contexts. Testing this hypothesis, however, went beyond the objectives of this article and remains as a task for further exploration. Secondly, we have seen that establishment and challenger parties represent two distinct types of party families in relation to the new politics conflict dimension. This implies that the regionalist party family is divided by the new politics conflict: old regionalist parties continue to emphasise centre-periphery issues more than any other type of party whereas new regionalist parties give more relative weight to the new politics dimension than to the centre-periphery one.

Ultimately, our article shows that regionalisation and the presence of a centre-periphery cleavage represent no obstacle when it comes to responding to a change of preferences among the electorate. The transformation of political spaces in Europe is happening as much, or more, at the regional level as at the national one. Meanwhile, the diversity of regional responses as 
well as the electoral weight and political relevance of challenger parties at the regional level negate the secondary nature of regional dynamics. Establishment parties have shown a considerable degree of responsiveness to the change of voters' preferences and their adaptation has followed mainly regional, not national, interests. 


\section{References}

Alonso, Sonia (2012). Challenging the State: Devolution and the Battle for Partisan Credibility. Oxford: Oxford University Press.

Alonso, Sonia, and Rubén Ruiz-Rufino (2018). 'The Costs of Responsibility for the Political Establishment of the Eurozone (1999-2015)', Party Politics, forthcoming.

Alonso, Sonia, Braulio Gómez, and Laura Cabeza (2013). 'Measuring Centre-Periphery Preferences: The Regional Manifestos Project', Regional \& Federal Studies, 23:2, 189211.

Alonso, Sonia, Laura Cabeza, and Braulio Gómez (2015). 'Parties' Electoral Strategies in a Two-dimensional Political Space: Evidence from Spain and Great Britain', Party Politics, $21: 6,851-65$.

Alonso, Sonia, Laura Cabeza, and Braulio Gómez (2017). 'Disentangling Peripheral Parties' Issue Packages in Subnational Elections', Comparative European Politics, 15:2, 240-63.

Armingeon, Klaus, Kai Guthmann, and David Weisstanner (2016). 'Choosing the Path of Austerity: How Parties and Policy Coalitions Influence Welfare State Retrenchment in Periods of Fiscal Consolidation', West European Politics, 39:4, 628-47.

Bågenholm, Andreas, and Nicholas Charron (2014). 'Do Politics in Europe Benefit from Politicising Corruption?', West European Politics, 37:5, 903-31.

Benoit, Kenneth, and Thomas Däubler (2014). 'Putting Text in Context: How to Estimate Better Left-Right Positions by Scaling Party Manifesto Data using Item Response Theory', 'Mapping Policy Preferences from Texts' Conference, Berlin.

Bosco, Anna, and Susannah Verney (2016). 'From Electoral Epidemic to Government Epidemic: The Next Level of the Crisis in Southern Europe', South European Society and Politics, 21:4, 383-406.

Casal Bértoa, Fernando (2014). 'Seismic Wave or Tsunami? Assessing Party System Change in Times of Crisis', $8^{\text {th }}$ ECPR General Conference, University of Glasgow.

Ceccarini, Luigi, and Fabio Bordignon (2016). 'The Five Stars Continue to Shine: The Consolidation of Grillo's 'Movement Party' in Italy', Contemporary Italian Politics, 8:2, 131-59.

Copelovitch, Mark, Jeffry Frieden, and Stefanie Walter (2016). 'The Political Economy of the Euro Crisis', Comparative Political Studies, 49:7, 811-40.

Däubler, Thomas, Jochen Müller, and Christian Stecker (2017). 'Assessing Democratic Representation in Multi-level Democracies', West European Politics, doi: 10.1080/01402382.2017.1409498.

Elias, Anwen, Edina Szöcsik, and Christina I. Zuber (2015). 'Position, Selective Emphasis and Framing: How Parties Deal with a Second Dimension in Competition', Party Politics, 21:6, 839-50.

Elias, Anwen, and Filippo Tronconi, eds. (2011). From Protest to Power: Autonomist Parties and the Challenges of Representation. Wien: Braumüller.

Ford, Robert, Matthew J. Goodwin, and David Cutts (2012). 'Strategic Eurosceptics and Polite Xenophobes: Support for the United Kingdom Independence Party (UKIP) in the 2009 European Parliament Elections', European Journal of Political Research, 51:2, 204-34. 
Gross, Martin, and Marc Debus (2017). 'Does EU Regional Policy Increase Parties' Support for European Integration?', West European Politics, doi: 10.1080/01402382.2017.1395249.

Gómez, Braulio, and Ignacio Urquizu (2015). 'Political Corruption and the End of Two-party System after the May 2015 Spanish Regional Elections', Regional \& Federal Studies, 25:4, 379-89.

Hernández, Enrique, and Hanspeter Kriesi (2016). 'The Electoral Consequences of the Financial and Economic Crisis in Europe', European Journal of Political Research, 55:2, 203-24.

Hobolt, Sara, and James Tilley (2016). 'Fleeing the Centre: The Rise of Challenger Parties in the Aftermath of the Euro Crisis', West European Politics, 39:5, 971-91.

Hutter, Swen, Hanspeter Kriesi, and Guillem Vidal (2017). 'Old versus New Politics. The Political Spaces in Southern Europe in Times of Crises', Party Politics, forthcoming.

Kriesi, Hanspeter (2014). 'The Populist Challenge', West European Politics, 37:2, 361-78.

Mair, Peter (2013). Ruling the Void: The Hollowing of Western Democracy. London: Verso.

Massetti, Emanuele (2009). 'Explaining Regional Party Positioning in a Multi-dimensional Ideological Space: A Framework for Analysis', Regional \& Federal Studies, 19:4-5, 50131 .

Massetti, Emanuele, and Arian H. Schakel (2015). 'From Class to Region: How Regionalist Parties Link (and Subsume) Left-right into Centre-periphery Politics', Party Politics, 21:6, 866-86.

Meguid, Bonnie (2008). Party Competition between Unequals. Cambridge: Cambridge University Press.

Muro, Diego, and Guillem Vidal (2017). 'Political Mistrust in Southern Europe since the Great Recession', Mediterranean Politics, 22:2, 197-217.

Orriols, Lluis, and Guillermo Cordero (2016). 'The Breakdown of the Spanish Two-Party System: The Upsurge of Podemos and Ciudadanos in the 2015 General Election', South European Society and Politics, 21:4, 469-92.

Rodríguez Teruel, Juan, and Astrid Barrio (2016). 'Going National: Ciudadanos from Catalonia to Spain', South European Society and Politics, 21:4, 587-607.

Rokkan, Stein, and Derek Urwin (1983). Economy, Territory, Identity. Politics of West European Peripheries. London: Sage Publications.

Ruiz-Rufino, Rubén, and Sonia Alonso (2017). 'Democracy without Choice: Citizens' Perceptions of Government Autonomy during the Eurozone Crisis', European Journal of Political Research, 56:2, 320-45.

Scantamburlo, Matthias, and Günther Pallaver (2014). 'The 2013 South Tyrolean Election: The End of SVP Hegemony', Regional \& Federal Studies, 24:4, 493-503.

Schakel, Arjan H., and Emanuele Massetti (2017). 'A World of Difference: The Sources of Regional Government Composition and Alternation', West European Politics, doi: 10.1080/01402382.2017.1400237. 
Thomassen, Jacques (1990). 'Economic Crisis, Dissatisfaction and Protest', in Kent Jennings et al. (eds.), Continuities in Political Action. A Longitudinal Study of Political Orientations in Three Western Democracies. Berlin/New York: Walter de Gruyter, 103-34.

Vampa, Davide (2015). 'The 2015 Regional Election in Italy: Fragmentation and Crisis of Subnational Representative Democracy', Regional \& Federal Studies, 25:4, 365-78.

Vampa, Davide (2016). The Regional Politics of Welfare in Italy, Spain and Great Britain. Basingstoke: Palgrave Macmillan.

Van Haute, Emilie, and Kris Deschouwer (2017). 'Federal reform and the quality of representation in Belgium', West European Politics, doi: 10.1080/01402382.2017.1399320.

Zuber, Christina I. (2012). 'Ethnic Party Competition Beyond the Segmented Market', Nationalities Papers, 40:6, 927-44. 


\section{Tables}

Table 1. New politics and economic austerity conflict dimensions: operationalisation with RMP policy categories.

\begin{tabular}{|l|l|}
\hline Dimension & RMP policy category \\
\hline New Politics & $\begin{array}{l}\text { 108 European Integration: Positive } \\
\text { 110 European Integration: Negative } \\
\text { 202 Democracy: Positive } \\
\text { 2024 Representative Democracy: Positive } \\
\text { 2025 Participatory Democracy: Positive } \\
\text { 304 Political Corruption: Negative }\end{array}$ \\
\hline Economic Austerity & $\begin{array}{l}\text { 401 Free Enterprise: Positive } \\
\text { 403 Market Regulation: Positive } \\
\text { 404 Economic Planning: Positive } \\
406 \text { Protectionism: Positive } \\
407 \text { Protectionism: Negative } \\
409 \text { Keynesian Demand Management: Positive } \\
412 \text { Controlled Economy: Positive } \\
413 \text { Nationalisation: Positive } \\
414 \text { Economic Orthodoxy: Positive }\end{array}$ \\
\hline
\end{tabular}

Source: Regional Manifestos Project: http://www.regionalmanifestosproject.com. 
Table 2. Evolution of the relative weight of each dimension of competition by region (pre- and post-2010)

\begin{tabular}{|c|c|c|c|c|c|c|}
\hline & \multicolumn{2}{|c|}{ Pre-2010 } & \multicolumn{2}{|c|}{$1^{\text {st }}$ _post-2010 } & \multicolumn{2}{|c|}{$2^{\text {nd }} \_$post-2010 } \\
\hline Region & $\begin{array}{l}\text { Ratio } \\
\text { _nprile }\end{array}$ & $\begin{array}{l}\text { Ratio } \\
\text { npcp }\end{array}$ & $\begin{array}{l}\text { Ratio } \\
\text { _nprile }\end{array}$ & $\begin{array}{l}\text { Ratio } \\
\text { _npcp }\end{array}$ & $\begin{array}{l}\text { Ratio } \\
\text { _nprile }\end{array}$ & $\begin{array}{l}\text { Ratio } \\
\text { npcp }\end{array}$ \\
\hline Aosta Valley & 0.34 & 0.79 & 0.35 & 0.89 & & \\
\hline Trentino & 0.17 & 0.37 & 0.22 & 0.56 & & \\
\hline South Tyrol & 0.36 & 0.30 & 0.43 & 0.31 & & \\
\hline Veneto & 0.25 & 0.56 & 0.31 & 2.24 & & \\
\hline Scotland & 0.03 & 0.24 & 0.13 & 0.56 & & \\
\hline Wales & 0.15 & 0.27 & 0.30 & 0.62 & & \\
\hline Balearic Is. & 0.18 & 0.77 & 0.20 & 0.60 & 0.38 & 1.22 \\
\hline Basque $\mathrm{C}$. & 0.21 & 0.67 & 0.15 & 0.37 & 0.21 & 0.46 \\
\hline Canary Is. & 0.12 & 0.68 & 0.08 & 0.33 & 0.31 & 2.04 \\
\hline Cantabria & 0.11 & 0.52 & 0.22 & 1.24 & 0.09 & 0.84 \\
\hline Catalonia & 0.14 & 0.42 & 0.23 & 0.36 & & \\
\hline Galicia & 0.16 & 0.29 & 0.19 & 0.39 & & \\
\hline Navarre & 0.16 & 0.46 & 0.14 & 0.50 & 0.32 & 0.89 \\
\hline
\end{tabular}


Table 3. The relative weight of the new politics, economic austerity and centre-periphery dimensions in regional party manifestos, by type of party (pre- and post-2010).

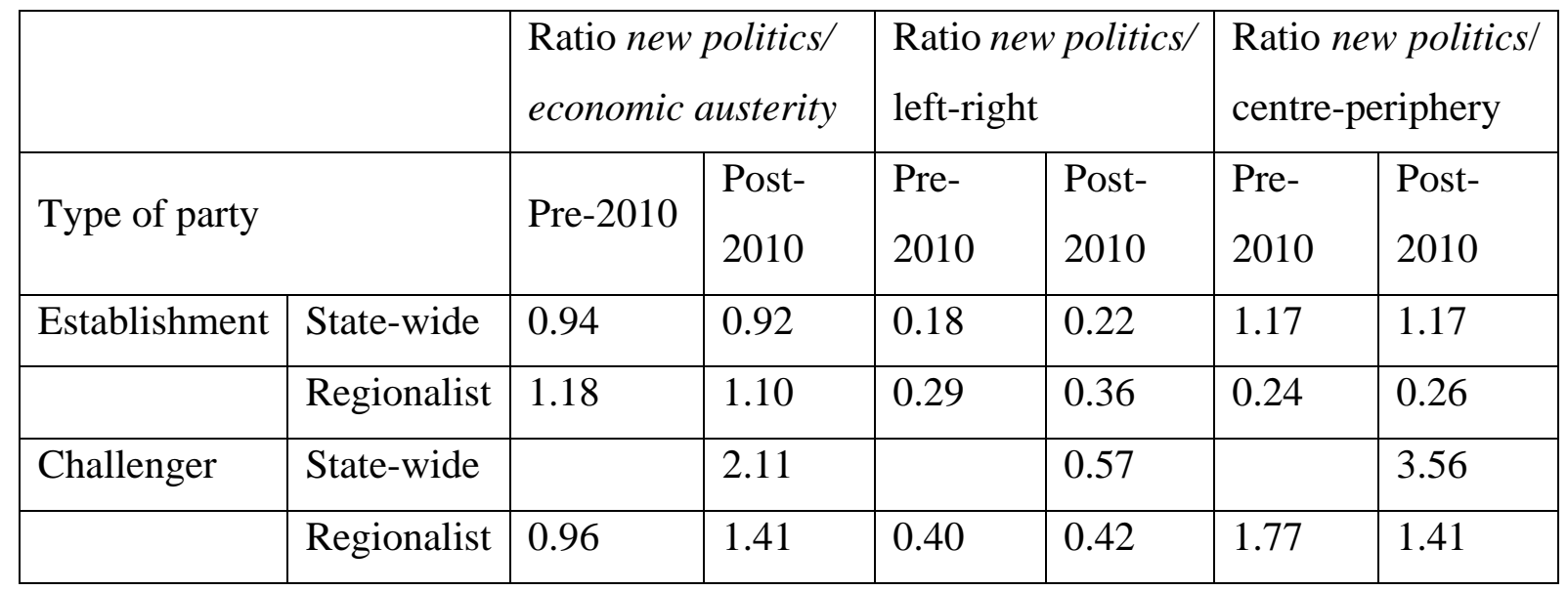




\section{Figures}

Figure 1. Salience of the major conflict dimensions in new challenger parties' regional manifestos (average for all years)

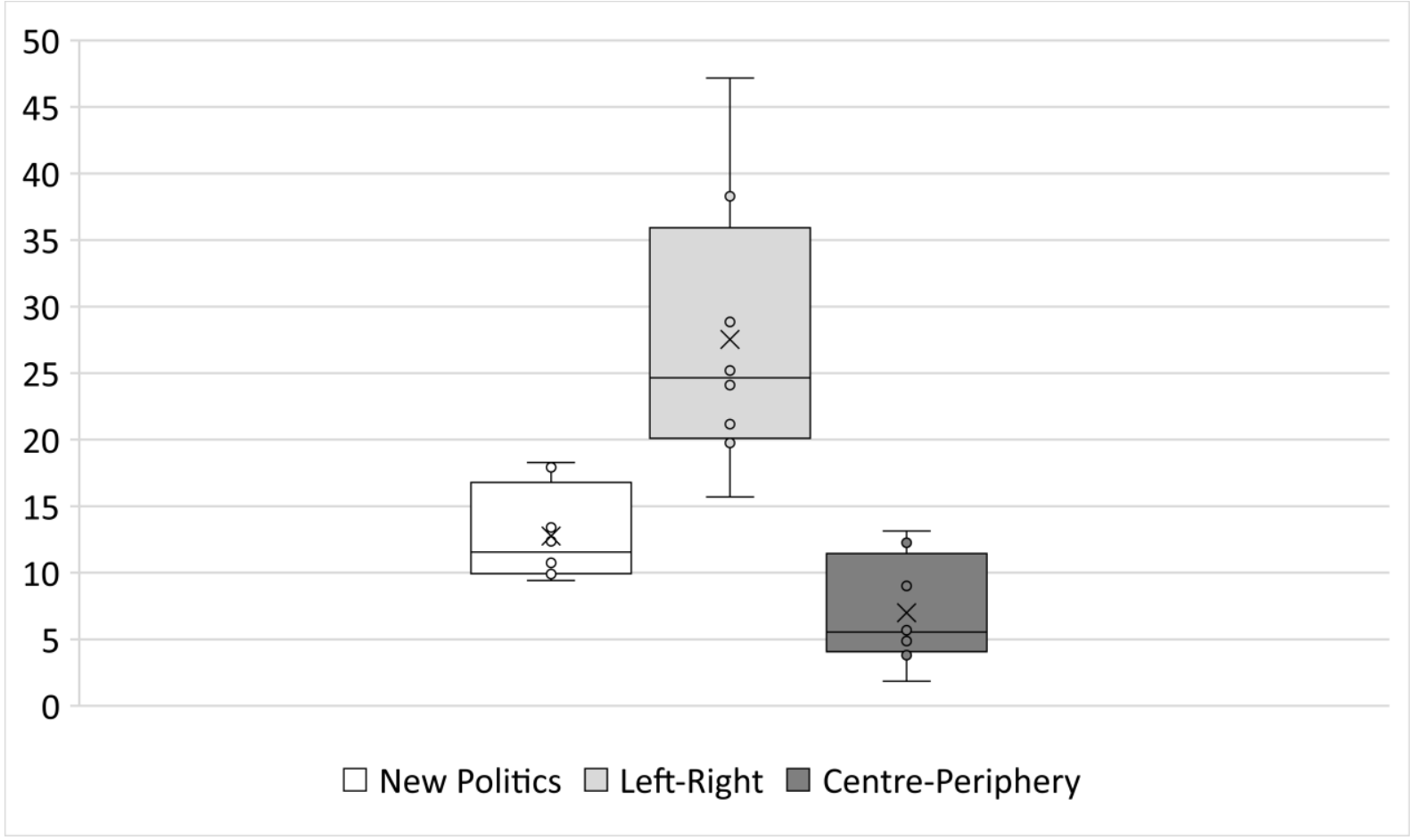


Figure 2. New politics versus economic austerity dimensions in challenger parties' regional manifestos (new politics + economic austerity $=100$ per cent $)^{*}$

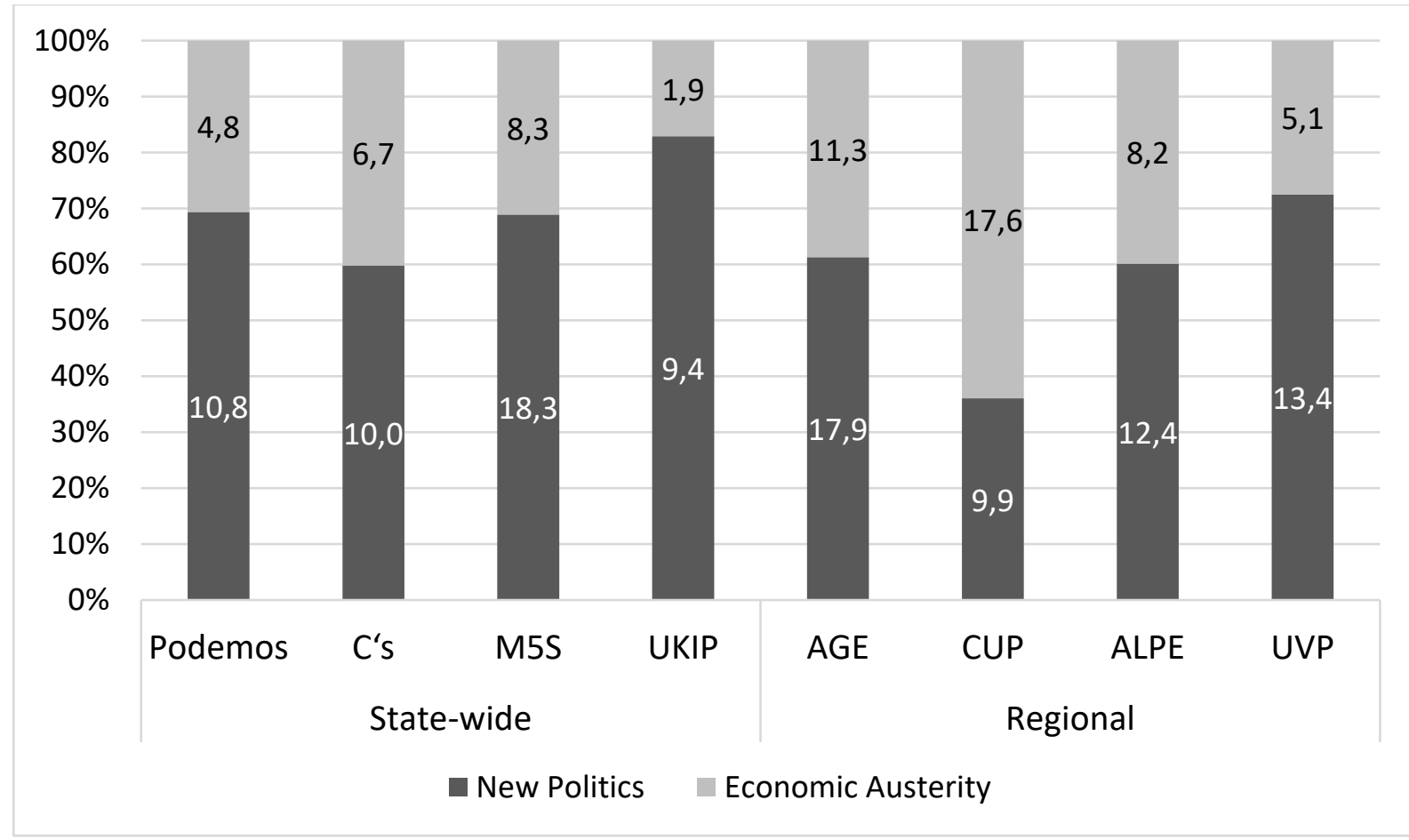

*Note: The values inside the columns represent each dimension's absolute salience score relative to the manifesto as a whole. 
Figure 3. Change in salience score of new politics and economic austerity issues by region (preand post 2010)*

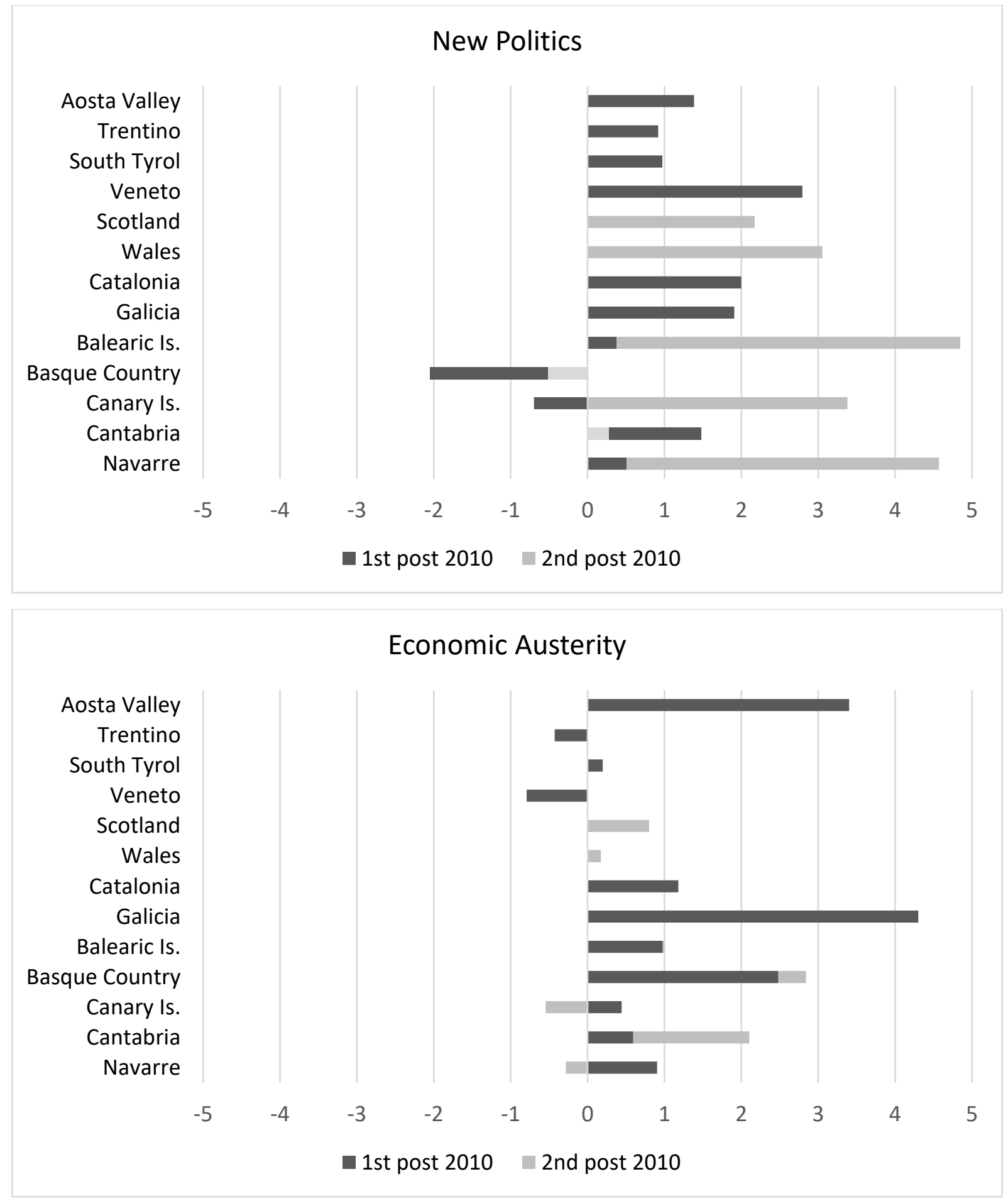

*Note: The values indicate the change in issue salience scores between the last electoral turnout before 2010 and the first after 2010. Where there have been two turnouts after 2010, columns have been subdivided in a $1^{\text {st }}$ and a $2^{\text {nd }}$ post 2010 period. For absolute values see table A5 in the Appendix. 
Figure 4. Evolution of the salience of new politics, economic austerity and centre-periphery conflict dimensions by type of party (pre- and post-2010)*

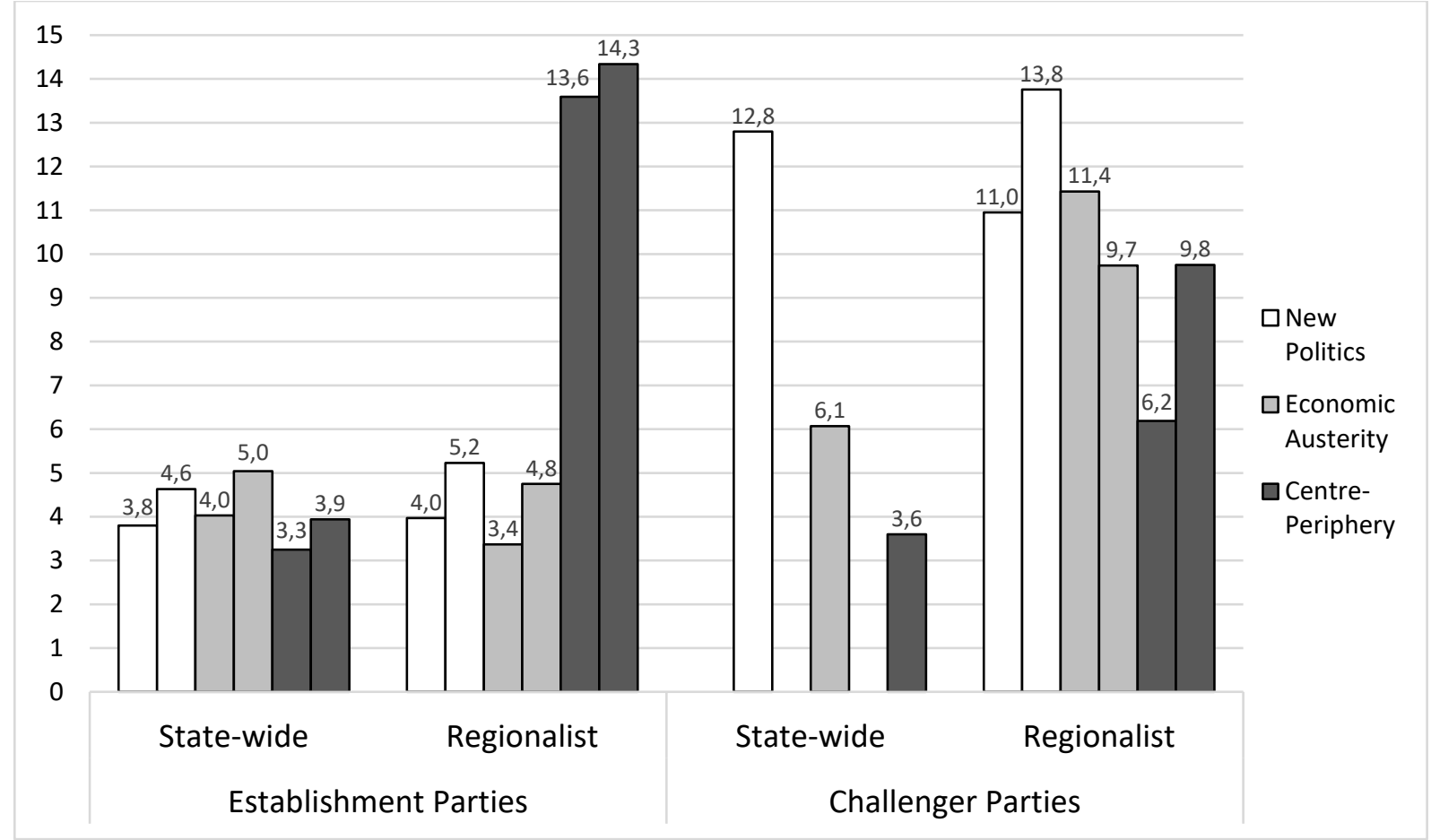

*Note: The values indicate absolute salience scores in regional manifestos comparing the last electoral turnout before 2010 (first column) and the elections after 2010 (second column). Where there have been two elections after 2010, the average value between the two has been taken. 


\section{Appendix}

Table A1. The RMP categories conforming the centre-periphery and left-right dimensions of electoral competition

The centre-periphery dimension

\begin{tabular}{|c|c|c|}
\hline & RMP Category & Definition \\
\hline \multirow[t]{5}{*}{ Centre } & C32_YYY(Y) & $\begin{array}{l}\text { All policy preference categories that come with a } 32 \text { code } \\
\text { (i.e. more competencies for the central state) }\end{array}$ \\
\hline & C21_YYY(Y) & $\begin{array}{l}\text { All policy preference categories that come with a } 21 \text { code } \\
\text { (i.e. fewer competencies for the peripheral territory) }\end{array}$ \\
\hline & $\begin{array}{l}\text { C30_(601,6015, } \\
6016,608)\end{array}$ & Promotion of [state] nation-building policies \\
\hline & C20_602 & Statements against peripheral nationalism or regionalism. \\
\hline & $\begin{array}{l}\text { C20_302+ } \\
\text { C30_302 }\end{array}$ & $\begin{array}{l}\text { General statements against decentralisation. In favour of } \\
\text { centralisation or re-centralisation at the state level. }\end{array}$ \\
\hline \multirow[t]{5}{*}{ Periphery } & C22_YYY(Y) & $\begin{array}{l}\text { All policy preference categories that come with a } 22 \text { code } \\
\text { (i.e. more competencies for the peripheral territory) }\end{array}$ \\
\hline & C31_YYY(Y) & $\begin{array}{l}\text { All policy preference categories that come with a } 31 \text { code } \\
\text { (i.e. fewer competencies for the central state) }\end{array}$ \\
\hline & $\begin{array}{l}\text { C20_(601, 6015, } \\
6016,608)\end{array}$ & Promotion of [regional] nationbuilding policies \\
\hline & C30_602 & $\begin{array}{l}\text { Statements against state nationalism or against the existing } \\
\text { nation-state }\end{array}$ \\
\hline & $\begin{array}{l}\text { C20_(301,3013, } \\
3014)+ \text { C30_301 }\end{array}$ & $\begin{array}{l}\text { General statements in favour of decentralisation at the } \\
\text { regional level }\end{array}$ \\
\hline
\end{tabular}

The left-right dimension

\begin{tabular}{|l|l|l|l|}
\hline Right & & Left & \\
\hline Category & Definition & Category & Definition \\
\hline c104 & Military: Positive & c103 & Anti-Imperialism \\
\hline c201 & Freedom and Human Rights & c105 & Military: Negative \\
\hline c30_203 & State Constitutionalism: Pos. & c106 & Peace \\
\hline c305 & Political Authority & c107 & Internationalism: Positive \\
\hline c401 & Free Enterprise: Positive & c202 & Democracy \\
\hline c402 & Incentives: Positive & c2024 & Representative Democracy: Pos. \\
\hline c407 & Protectionism: Negative & c2025 & Participatory Democracy: Positive \\
\hline c414 & Economic Orthodoxy: Positive & c403 & Market Regulation: Positive \\
\hline c505 & Welfare State Limitation & c404 & Economic Planning: Positive \\
\hline c507 & Education Limitation & c406 & Protectionism: Positive \\
\hline c603 & Traditional Morality: Positive & c412 & Controlled Economy: Positive \\
\hline c605 & Law and Order: Positive & c413 & Nationalisation: Positive \\
\hline c606 & Civic Mindedness: Positive & c701 & Labour Groups: Positive \\
\hline
\end{tabular}


Table A2. Selected parties (new challenger parties in bold)

\begin{tabular}{|c|c|c|c|c|}
\hline Country & Region & Type & Party & Abbr. \\
\hline \multirow[t]{8}{*}{ Italy } & \multirow[t]{2}{*}{ Aosta Valley } & Regionalist & $\begin{array}{l}\text { Union Valdôtaine } \\
\text { Stella Alpina } \\
\text { Union Valdôtaine Progressiste } \\
\text { Autonomie Liberté Participation } \\
\text { Ecologie - Renouveau Valdôtain }\end{array}$ & $\begin{array}{l}\text { UV } \\
\text { SA } \\
\text { UVP } \\
\text { ALPE }\end{array}$ \\
\hline & & State-wide & $\begin{array}{l}\text { Partito Democratico } \\
\text { Movimento Cinque Stelle }\end{array}$ & $\begin{array}{l}\text { PD } \\
\text { M5S }\end{array}$ \\
\hline & \multirow[t]{2}{*}{ South Tyrol } & Regionalist & $\begin{array}{l}\text { Südtiroler Volkspartei } \\
\text { Die Freiheitlichen } \\
\text { Süd-Tiroler Freiheit }\end{array}$ & $\begin{array}{l}\text { SVP } \\
\text { DF } \\
\text { STF }\end{array}$ \\
\hline & & State-wide & $\begin{array}{l}\text { Partito Democratico } \\
\text { Movimento Cinque Stelle }\end{array}$ & $\begin{array}{l}\text { PD } \\
\text { M5S }\end{array}$ \\
\hline & \multirow[t]{2}{*}{ Trentino } & Regionalist & $\begin{array}{l}\text { Partito Autonomista Trentino Tirolese } \\
\text { Lega Nord Trentino }\end{array}$ & $\begin{array}{l}\text { PATT } \\
\text { LN }\end{array}$ \\
\hline & & State-wide & $\begin{array}{l}\text { Partito Democratico } \\
\text { Movimento Cinque Stelle }\end{array}$ & $\begin{array}{l}\text { PD } \\
\text { M5S }\end{array}$ \\
\hline & \multirow[t]{2}{*}{ Veneto } & Regionalist & Lega Nord Veneto & LN \\
\hline & & State-wide & $\begin{array}{l}\text { Partito Democratico } \\
\text { Movimento Cinque Stelle }\end{array}$ & $\begin{array}{l}\text { PD } \\
\text { M5S }\end{array}$ \\
\hline \multirow[t]{11}{*}{ Spain } & \multirow[t]{2}{*}{ Basque $\mathrm{C}$. } & Regionalist & $\begin{array}{l}\text { Partido Nacionalista Vasco } \\
\text { Euskal Herria Bildu }\end{array}$ & $\begin{array}{l}\text { PNV } \\
\text { EHB }\end{array}$ \\
\hline & & State-wide & $\begin{array}{l}\text { Partido Socialista } \\
\text { Partido Popular } \\
\text { Podemos }\end{array}$ & $\begin{array}{l}\text { PSOE } \\
\text { PP } \\
\text { Pod }\end{array}$ \\
\hline & \multirow[t]{2}{*}{ Canary Is. } & Regionalist & Coalición Canaria & $\mathrm{CC}$ \\
\hline & & State-wide & $\begin{array}{l}\text { Partido Socialista } \\
\text { Partido Popular } \\
\text { Podemos }\end{array}$ & $\begin{array}{l}\text { PSOE } \\
\text { PP } \\
\text { Pod }\end{array}$ \\
\hline & \multirow[t]{2}{*}{ Cantabria } & Regionalist & Partido Regionalista Cantabro & PRC \\
\hline & & State-wide & $\begin{array}{l}\text { Partido Socialista } \\
\text { Partido Popular } \\
\text { Podemos } \\
\text { Ciudadanos }\end{array}$ & $\begin{array}{l}\text { PSOE } \\
\text { PP } \\
\text { Pod } \\
\text { C's }\end{array}$ \\
\hline & \multirow[t]{2}{*}{ Balearic Is. } & Regionalist & $\begin{array}{l}\text { Més per Mallorca - Partit Socialista de } \\
\text { Mallorca }\end{array}$ & Més \\
\hline & & State-wide & $\begin{array}{l}\text { Partido Socialista } \\
\text { Partido Popular } \\
\text { Podemos } \\
\text { Ciudadanos }\end{array}$ & $\begin{array}{l}\text { PSOE } \\
\text { PP } \\
\text { Pod } \\
\text { C's }\end{array}$ \\
\hline & \multirow[t]{2}{*}{ Catalonia } & Regionalist & $\begin{array}{l}\text { Convergència y Unió } \\
\text { Esquerra Republicana de Catalunya } \\
\text { Candidatura de Unidad Popular }\end{array}$ & $\begin{array}{l}\text { CiU } \\
\text { ERC } \\
\text { CUP }\end{array}$ \\
\hline & & State-wide & $\begin{array}{l}\text { Partido Socialista Obrero Español } \\
\text { Partido Popular } \\
\text { Ciudadanos }\end{array}$ & $\begin{array}{l}\text { PSOE } \\
\text { PP } \\
\text { C's }\end{array}$ \\
\hline & Galicia & Regionalist & $\begin{array}{l}\text { Bloque Nacionalista Gallego } \\
\text { Alternativa Galega de Esquerda }\end{array}$ & $\begin{array}{l}\text { BNG } \\
\text { AGE }\end{array}$ \\
\hline
\end{tabular}




\begin{tabular}{|l|l|l|l|l|}
\hline & & State-wide & $\begin{array}{l}\text { Partido Socialista Obrero Español } \\
\text { Partido Popular }\end{array}$ & $\begin{array}{l}\text { PSOE } \\
\text { PP }\end{array}$ \\
\hline & Navarre & Regionalist & $\begin{array}{l}\text { Union del Pueblo Navarro } \\
\text { Geroa Bai - Nafarroa Bai } \\
\text { Euskal Herria Bildu }\end{array}$ & $\begin{array}{l}\text { UPN } \\
\text { GeBai } \\
\text { EHB }\end{array}$ \\
\cline { 3 - 5 } & State-wide & $\begin{array}{l}\text { Partido Socialista Obrero Español } \\
\text { Podemos }\end{array}$ & $\begin{array}{l}\text { PSOE } \\
\text { Pod }\end{array}$ \\
\hline $\begin{array}{l}\text { Great } \\
\text { Britain }\end{array}$ & Scotland & Regionalist & Scottish National Party & SNP \\
\hline & State-wide & $\begin{array}{l}\text { Labour Party } \\
\text { Conservative Party }\end{array}$ & $\begin{array}{l}\text { Lab } \\
\text { Cons }\end{array}$ \\
\hline & Wales & Regionalist & Plaid Cymru & PC \\
\cline { 3 - 5 } & State-wide & $\begin{array}{l}\text { Labour Party } \\
\text { Conservative Party } \\
\text { United Kingdom Independence Party }\end{array}$ & $\begin{array}{l}\text { Lab } \\
\text { Cons } \\
\text { UKIP }\end{array}$ \\
\hline
\end{tabular}


Table A3. New challenger parties' electoral results 2007-2016

\begin{tabular}{|c|c|c|c|c|c|}
\hline Country & Party & Year & Region & $\%$ & Seats \\
\hline \multirow[t]{8}{*}{ Italy } & \multirow[t]{5}{*}{ Movimento Cinque Stelle } & 2010 & Veneto & 2.58 & $0 / 51$ \\
\hline & & 2013 & Aosta Valley & 6.52 & $2 / 35$ \\
\hline & & & South Tyrol & 2.5 & $1 / 35$ \\
\hline & & & Trentino & 5.72 & $2 / 35$ \\
\hline & & 2015 & Veneto & 10.40 & $5 / 51$ \\
\hline & \multirow[t]{2}{*}{ Autonomie Liberté Participation Ecologie ${ }^{1}$} & 2008 & Aosta Valley & 12.48 & $5 / 35$ \\
\hline & & 2013 & Aosta Valley & 12.41 & $5 / 35$ \\
\hline & Union Valdôtaine Progressiste & 2013 & Aosta Valley & 19.21 & $7 / 35$ \\
\hline \multirow[t]{15}{*}{ Spain } & \multirow[t]{7}{*}{ Podemos } & 2015 & Balearic Is. & 14.69 & $10 / 5$ \\
\hline & & & Canary Is. & 14.53 & $7 / 60$ \\
\hline & & & Cantabria & 8.83 & $3 / 35$ \\
\hline & & & Catalonia $^{2}$ & 8.94 & $11 / 135$ \\
\hline & & & Navarre & 13.67 & $7 / 50$ \\
\hline & & 2016 & Basque C. & 14.76 & $11 / 75$ \\
\hline & & & Galicia $^{3}$ & 19.07 & $14 / 75$ \\
\hline & \multirow[t]{5}{*}{ Ciudadanos } & 2010 & Catalonia & 3.40 & $3 / 135$ \\
\hline & & 2012 & Catalonia & 7.56 & $9 / 135$ \\
\hline & & 2015 & Balearic Is. & 5.92 & $2 / 59$ \\
\hline & & & Cantabria & 6.62 & $2 / 35$ \\
\hline & & & Catalonia & 17.90 & $25 / 135$ \\
\hline & \multirow[t]{2}{*}{ Candidatura de Unidad Popular } & 2012 & Catalonia & 3.47 & $3 / 135$ \\
\hline & & 2015 & Catalonia & 8.21 & $10 / 135$ \\
\hline & Alternativa Galega de Esquerda & 2012 & Galicia & 13.91 & $9 / 75$ \\
\hline \multirow{3}{*}{$\begin{array}{l}\text { Great } \\
\text { Britain }\end{array}$} & \multirow[t]{3}{*}{ United Kingdom Independence Party } & 2007 & Wales & 4.0 & $0 / 20$ \\
\hline & & 2011 & Wales & 4.6 & $0 / 20$ \\
\hline & & 2016 & Wales & 13.0 & $7 / 20$ \\
\hline
\end{tabular}

1 Coalition, founded as Renouveau Valdôtain in 2008

2 Catalunya Sí que es Pot (Coalition)

3 En Marea (Coalition) 
Table A4. Analysed Elections by Region

\begin{tabular}{|l|l|l|}
\hline Country & Region & Elections \\
\hline \multirow{5}{*}{ Italy } & Aosta Valley & 2008,2013 \\
\cline { 2 - 3 } & Trentino & 2008,2013 \\
\cline { 2 - 3 } & South Tyrol & 2008,2013 \\
\cline { 2 - 3 } & Veneto & 2010,2015 \\
\hline \multirow{5}{*}{ Spain } & Balearic Islands & $2007,2011,2015$ \\
\cline { 2 - 3 } & Basque Country & $2009,2012,2016$ \\
\cline { 2 - 3 } & Canary Islands & $2007,2011,2015$ \\
\cline { 2 - 3 } & Cantabria & $2007,2011,2015$ \\
\cline { 2 - 3 } & Catalonia & 2010,2012 \\
\cline { 2 - 3 } & Galicia & 2009,2012 \\
\cline { 2 - 3 } & Navarre & $2007,2011,2015$ \\
\hline Great Britain & Scotland & 2011,2016 \\
\cline { 2 - 3 } & Wales & 2011,2016 \\
\hline
\end{tabular}

Note: Regarding Scotland and Wales, we lack data for the last pre-2010 regional election. Therefore, we include the two post-2010 regional elections (2011 and 2016) in our dataset. Although it does not allow us to see the hypothesised change, at least it shows a change between two electoral periods. 
Table A5. Evolution of new politics and economic austerity salience in the space of political competition by region pre- and post-2010 (standard deviations in brackets)

\begin{tabular}{|c|c|c|c|c|c|c|}
\hline \multirow[b]{2}{*}{ Region } & \multicolumn{3}{|c|}{ New politics salience score } & \multicolumn{3}{|c|}{ Economic austerity salience score } \\
\hline & Pre-2010 & $\begin{array}{l}1^{\text {st }} \text { post- } \\
2010\end{array}$ & $\begin{array}{l}2^{\text {nd }} \text { post- } \\
2010\end{array}$ & Pre-2010 & $\begin{array}{l}1^{\text {st }} \text { post- } \\
2010\end{array}$ & $\begin{array}{l}2^{\text {nd }}-\text { post- } \\
2010\end{array}$ \\
\hline Aosta Valley & $\begin{array}{l}7.11 \\
(2.42) \\
\end{array}$ & $\begin{array}{l}8.50 \\
(3.91) \\
\end{array}$ & & $\begin{array}{l}3.61 \\
(1.80) \\
\end{array}$ & $\begin{array}{l}7.01 \\
(2.01) \\
\end{array}$ & \\
\hline Trentino & $\begin{array}{l}4.14 \\
(2.40)\end{array}$ & $\begin{array}{l}5.05 \\
(1.85)\end{array}$ & & $\begin{array}{l}5.71 \\
(2.30)\end{array}$ & $\begin{array}{l}5.29 \\
(2.62)\end{array}$ & \\
\hline South Tyrol & $\begin{array}{l}6.65 \\
(3.46) \\
\end{array}$ & $\begin{array}{l}7.62 \\
(1.37) \\
\end{array}$ & & $\begin{array}{l}2.11 \\
(0.88)\end{array}$ & $\begin{array}{l}2.30 \\
(1.68)\end{array}$ & \\
\hline Veneto & $\begin{array}{l}4.74 \\
(0.01) \\
\end{array}$ & $\begin{array}{l}7.53 \\
(0.08) \\
\end{array}$ & & $\begin{array}{l}4.79 \\
(0.62) \\
\end{array}$ & $\begin{array}{l}4.00 \\
(0.35) \\
\end{array}$ & \\
\hline Scotland & & $\begin{array}{l}0.78 \\
(0.41)\end{array}$ & $\begin{array}{l}2.95 \\
(0.79)\end{array}$ & & $\begin{array}{l}5.01 \\
(1.21)\end{array}$ & $\begin{array}{l}5.81 \\
(1.96)\end{array}$ \\
\hline Wales & & $\begin{array}{l}2.30 \\
(0.59)\end{array}$ & $\begin{array}{l}5.35 \\
(1.91)\end{array}$ & & $\begin{array}{l}4.46 \\
(0.80)\end{array}$ & $\begin{array}{l}4.63 \\
(1.13)\end{array}$ \\
\hline Balearic Is. & $\begin{array}{l}3.01 \\
(1.77) \\
\end{array}$ & $\begin{array}{l}3.39 \\
(1.82) \\
\end{array}$ & $\begin{array}{l}7.86 \\
(3.32) \\
\end{array}$ & $\begin{array}{l}4.22 \\
(1.63)\end{array}$ & $\begin{array}{l}5.20 \\
(0.65) \\
\end{array}$ & $\begin{array}{l}4.24 \\
(2.49) \\
\end{array}$ \\
\hline Basque $\mathrm{C}$. & $\begin{array}{l}5.55 \\
(1.16)\end{array}$ & $\begin{array}{l}3.50 \\
(1.52)\end{array}$ & $\begin{array}{l}5.03 \\
(1.78)\end{array}$ & $\begin{array}{l}2.35 \\
(0.81)\end{array}$ & $\begin{array}{l}4.83 \\
(0.77)\end{array}$ & $\begin{array}{l}5.19 \\
(0.48)\end{array}$ \\
\hline Canary Is. & $\begin{array}{l}2.18 \\
(1.43) \\
\end{array}$ & $\begin{array}{l}1.48 \\
(0.22) \\
\end{array}$ & $\begin{array}{l}5.56 \\
(4.14) \\
\end{array}$ & $\begin{array}{l}4.00 \\
(1.53) \\
\end{array}$ & $\begin{array}{l}4.44 \\
(3.71) \\
\end{array}$ & $\begin{array}{l}3.46 \\
(0.90) \\
\end{array}$ \\
\hline Cantabria & $\begin{array}{l}1.59 \\
(0.35) \\
\end{array}$ & $\begin{array}{l}3.07 \\
(1.14) \\
\end{array}$ & $\begin{array}{l}1.87 \\
(1.86) \\
\end{array}$ & $\begin{array}{l}2.83 \\
(1.11) \\
\end{array}$ & $\begin{array}{l}3.42 \\
(1.97) \\
\end{array}$ & $\begin{array}{l}4.93 \\
(0.65) \\
\end{array}$ \\
\hline Catalonia & $\begin{array}{l}3.15 \\
(0.54) \\
\end{array}$ & $\begin{array}{l}5.14 \\
(2.23) \\
\end{array}$ & & $\begin{array}{l}5.51 \\
(0.78) \\
\end{array}$ & $\begin{array}{l}6.69 \\
(0.90) \\
\end{array}$ & \\
\hline Galicia & $\begin{array}{l}2.09 \\
(0.28) \\
\end{array}$ & $\begin{array}{l}4.00 \\
(1.06) \\
\end{array}$ & & $\begin{array}{l}3.86 \\
(0.94) \\
\end{array}$ & $\begin{array}{l}8.16 \\
(1.38) \\
\end{array}$ & \\
\hline Navarre & $\begin{array}{l}2.17 \\
(0.68)\end{array}$ & $\begin{array}{l}2.68 \\
(1.47)\end{array}$ & $\begin{array}{l}6.74 \\
(3.10)\end{array}$ & $\begin{array}{l}1.98 \\
(0.20)\end{array}$ & $\begin{array}{l}2.88 \\
(0.09)\end{array}$ & $\begin{array}{l}1.70 \\
(0.64)\end{array}$ \\
\hline
\end{tabular}

